Anna Stepčenko, Laura Jaunromāne

\title{
lesaistī̌̌ana un iesaistīšanās līdzdalībai pārmaiņu procesā
}

\author{
Involvement of the Social Service Providers \\ and End Users in Process of Change
}

\begin{abstract}
Summary
Social involvement is a path to empowerment aimed at promoting capability of the end users of the social services to engage in changing their own living conditions. The project SEMPRE applied involvement since its very beginning - needs assessment at the outset as the first step to proceed toward practical action.

The article describes the methods of social service end users' involvement in their needs assessment in SEMPRE. These methods include participatory rapid appraisal, backpack method, future workshop, and logical framework approach.

Seven examples are provided to show the best practice of involving social service end users and the positive results attained through that involvement. The article also contains information on start of microprojects in five localities of Kurzeme region, Latvia - five microprojects dedicated to persons with disabilities realized by the representatives of this target group themselves in Grobin,a, Bārta, Rucava, Durbe un Dubeņi rural municipalities.
\end{abstract}

A supplementary information received in June 2018 by project partners on implementation of 12 microprojects is also included.

Finally, the article describes the actual involvement in food supply programme "Your own contribution to your family table" ("Pats savam saimes galdam") for poor and low-income people in rural areas of Latvia.

Key words: involvement methods of social service end users in needs assessment and service provision, best praxis examples of involvement, actual involvement praxis - microprojects in Kurzeme region of Latvia and partner countries. 


\section{Kopsavilkums}

Sociālo pakalpojumu galalietotāju iesaistǐšanas un iesaistǐšanās process ir līdzdalības pirmelements un iesākums spēcināšanai, lai šos cilvēkus motivētu uzṇemties atbildību būt aktīviem savas dzīves veidotājiem. Iesaistǐšanas/iesaistīšanās efektivitāte SEMPRE projektā tiek pārbaudīta mikroprojektos, kas tiek īstenoti kopprojekta ietvaros. Iesaistǐšana/iesaistǐšanās tiek aizsākta ar vajadzību apzināšanu. Rakstā ir sniegta informācija par četrām metodēm, kas iesaista galalietotājus un kas izmantotas vajadzību apzināšanā. Tās ir: 1) ātrais līdzdalīgais novērtējums (participatory rapid appraisal), 2) mugursomas metode (backpack method), 3) nākotnes darbnīca (future workshop) un 4) logiskās strukturēšanas pieejas metode (logical framework approach).

To, kā var notikt iesaistǐšana/iesaistī̌sanās sociālo pakalpojumu galalietotāju praktiskā savas dzīves apstākḷu uzlabošanā, ilustrē septiṇu îstenotu labas prakses piemēru apraksti.

Ieskatu par praktisko sociālo pakalpojumu lietotāju iesaistī̌̌anas/iesaistīšanās norisi Latvijā sniedz to mikroprojektu apraksti, kas tiek īstenoti Kurzemes reǵiona piecās apdzīvotās vietās: Grobiṇā, Bārtā, Rucavā, Durbē un Dubeņos. Kurzemē mikroprojektu īstenošanā savas dzives kvalitātes uzlabošanā ir iesaistītas personas ar invaliditāti. Iesaistǐšanas/iesaistī̌anās praksi papildina 12 mikroprojektu apraksti, kas 2018. gada jūnijā saņemti no projekta partneriem.

Noslēgumā ir sniegta informācija par 2018. gada sākumā izteikto piedāvājumu trūcīgiem sociālo pakalpojumu galalietotājiem Latvijā iesaistīties programmā "Pats savam saimes galdam", lai atvieglotu savus dzīves apstākḷus, sagādājot sev daļu pārtikas un to izaudzējot pašiem.

Atslēgvārdi: sociālo pakalpojumu galalietotāju iesaistīšanas metodes vajadzību apzināšanā, mikroprojekti kā iesaistīšanas/iesaistīšanās labās prakses piemēri vajadzību apmierināšanā un dzīves kvalitātes uzlabošanā.

Tematika. Sociālo pakalpojumu galalietotāju iesaistīšana savu vajadzību apzināšanā. Četras līdzdalīgās metodes savu vajadzību apzināšanā. Septiṇi labas prakses piemēri. Mikroprojekti Kurzemes reǵionā. 12 mikroprojekti, kurus īstenojuši SEMPRE projekta partneri citās valstīs. Borisa un Ināras Teterovu fonda piedāvājums Latvijas trūcīgām un maznodrošinātām ǵimenēm iesaistīties pārtikas sagādē, lai uzlabotu savu dzīves kvalitāti. Ieteicamās papildliteratūras un avotu saraksts.

Sociālo pakalpojumu galalietotāju sociālā iesaistišana un iesaistî̌̌nās ir norise, kas neškirami, nenodalāmi un organiski saistīta ar spēcināšanas procesu. Šai procesuālajā norisē ir spēcināmi un tiek spēcināti gan sociālo pakalpojumu organizāciju personāls, gan sociālo pakalpojumu lietotāji. 
Sociālo pakalpojumu galalietotāju iesaistīšana tiek uzskatīta par nepieciešamu visa procesa gaitā, sākot ar iesaistǐšanu un iesaistǐ̌anos savu vajadzību apzināšanā un to formulēšanu vārdos un beidzot ar procesa noslēdzošo posmu - rīcību, lai līdzdarbotos savu vajadzību apmierināšanai. Ši pieeja sociālo pakalpojumu galalietotājus uzlūko par savas dzīves ekspertiem, kas pārzina savas vajadzības un, dažādos veidos spēcināti, piedalās savu vajadzību apmierināšanas procesā.

Jēdzienu un ideju skaidrojums saskan̄ā ar SEMPRE projekta orientāciju uz praktisko lietderību ir lakonisks, jo skaidrojuma mērḳis ir radīt formu, kurā iekḷaujams praktiskās rīcības saturs. Tas nozīmē, ka projekta īstenošanā un pārskatā par projektu apzināti izslēgti centieni, cik vien iespējams plaši un visaptveroši sniegt teorētisko izklāstu par jēdzienu un ideju vēsturi un pieejām to skaidrošanā. Tā vietā vien raksturota jēdzienu un ideju būtība, lai tie līdzīgi bākai kalpotu par cel̦vedi praktiskai rīcībai.

Teorētiskais karkass par iesaistî̌anu un iesaistǐšanos ir balstīts uz humānistisko cilvēka dabas izpratni, kas nozìmē cieņu pret indivīdu, ticību indivīdam, uzskatu, ka indivīds spēj definēt savas dzìves situāciju, viņam ir tiesības to mainìt, viņam piemìt spēks to mainīt un viņam ir vai viņš var iegūt zināšanas un prasmes, kā to mainīt (Schrötter Johannsen, 2018).

\section{Līdzdalīgās metodes sociālo pakalpojumu galalietotāju vajadzību apzināšanā}

Sociālo pakalpojumu galalietotāju iesaistīšana savu vajadzību apmierināšanas procesā tiek iesākta ar viņu iesaistī̌sanu savu vajadzību apzināšanā.

SEMPRE projekta ietvaros partneriem ir piedāvātas četras metodes, kā apzināt viṇu dažādo mērķgrupu vajadzības, atbilstoši spēcināšanas idejai iesaistot pašus sociālo pakalpojumu galalietotājus. Partneri vēlas rūpēties par dažādām sociālām grupām, kurām palīdzība ir nepieciešama, un sniegt tām palīdzīgu roku, un viṇi ir izvēlējušies atšḳirīgas metodes, kā noskaidrot šo grupu vajadzības.

Ziemel̦vācijas Evaṇgêeliski luteriskās baznīcas dienests darba lietās (Kirchlicher Dienst in der Arbeitswelt, KAD) ir lietojis ātro līdzdalīgo 
novērtējumu (participatory rapid appraisal), Jiveskiles Universitātes konsorcija pārstāvji Kokolā (University of Jyväskylä, Kokkola), Somijā, ir iecienijiuši izmantot mugursomas metodi (backpack method), Zviedrijas konsultatīvā ekonomiskā apvienība sociālās uzṇēmējdarbības jautājumos Coompanion Nord dod priekšroku nākotnes darbnīcas metodei (future workshop) un log̣iskās strukturēšanas pieejai (logical framework approach). Turpinājumā īss katras piedāvātās metodes apraksts, kas balstās uz partneru iesūtīto informāciju.

\section{1. Ātrais līdzdalīgais novērtējums (participatory rapid appraisal)}

Ātrais līdzdalīgais novērtējums ir ērti izmantojama metode, ja nepieciešams ātri novērtēt situāciju, ņemot vērā kopienas un/vai sociālo pakalpojumu galalietotāju zināšanas un viedokḷus. Metode labi noder attīstības projektu un programmu plānošanā un ìstenošanā. Kopienas un/vai sociālo pakalpojumu galalietotāju iesaiste ne tikai veicina kāda projekta attīstību, bet arī spēcina pašu kopienu un/vai sociālo pakalpojumu galalietotājus. Ātrais līdzdalīgais novērtējums iesaista iedzīvotājus savas problēmsituācijas novērtēšanā, sasniedzamo mērḳu izvirzīšanā un sasniegtā novērtēšanā. Vadmotīvs šai metodē ir ideja, ka sociālo pakalpojuma galalietotāji paši ir savu dzīves situāciju eksperti.

Ziemel̦vācijas Evaņgéliski luteriskās baznīcas dienests darba lietās šo metodi ierasti lieto, strādājot kopā ar studentiem un noskaidrojot ilgstošo bezdarbnieku vajadzības. Šāda pētijuma laika grafiks ir sadalìts tā, ka, intensīvi un kopīgi strādājot vienu nedẹlu, šai nedēḷā divas dienas tiek veltitas studentu sagatavošanai, lai veiktu intervijas, trīs dienas noris intervijas un kopīgas aktivitātes ar kopienu un/ vai sociālo pakalpojumu galalietotājiem, un divas dienas tiek veltītas iegūtās informācijas apstrādei, interpretācijai un prezentācijām, uz kurām aicināti gan sociālo pakalpojumu sniedzēji, gan galalietotāji. Prezentācijās tiek ieteikts izmantot radošu pieeju un vizuālas metodes, veidot dialogu starp uzaicinātajiem pakalpojumu sniedzējiem un pakalpojumu galalietotājiem. Šīs metodes pozitīvie aspekti ir šādi: rezultāts iegūstams ātri - jau nedēḷas laikā, iesaistītie studenti parasti ir motivēti, sociālo pakalpojumu galalietotāji - patīkami pārsteigti par studentu entuziasmu un radošumu rezultātu prezentēšanā, prezentācijas pasākumā veidojas dialogs starp sociālo pakalpojumu sniedzējiem 
un galalietotājiem. Negatīvie aspekti ir apjomīgais darbs, kas nepieciešams, lai sagatavotu visu nepieciešamo intensivvajai darba nedēḷai, - it sevišķi, lai iesaistītu universitātes administrāciju un lai tā atbalstìtu studentu iekḷaušanu. Izvēelētā nedēḷa pētījuma veikšanai ir lielā mērā atkarīga no universitātes mācību grafika. Arī sociālo pakalpojumu galalietotāju sasniegšana un iesaistī̌sana var sagādāt grūtības. Rezultātu izmantošana un konkrēto identificēto nākamo soḷu realizācija atkarīga no pakalpojuma sniedzēju interesēm un motivācijas.

\subsection{Mugursomas metode (backpack method)}

Mugursomas metodi ir izmantojuši SEMPRE projekta Somijas partneri, strādājot ar bēgliem. Ši metode palīdz veidot sadarbību ar sociālo pakalpojumu galalietotājiem, šajā gadījumā - ar bēgliem. Tiek veidota kopīga darba grupa, kurā iesaistās gan sociālo pakalpojumu sniedzēji, gan pakalpojumu galalietotāji. Šai darba grupai tiek organizētas kopīgas sapulces un tikšanās, kurās tiek izskaidrots par pieejamiem pakalpojumiem, tiek uzklausīta pakalpojumu lietotāju pieredze un vēlmes, tiek veidota sadarbība un diskusija. Vajadzību noskaidrošanā var tikt veikta vienkārša aptauja un tikt organizēta paplašināta diskusija, tajā iesaistot nevalstiskas organizācijas (NVO) vai asociāciju pārstāvjus, kas ir ieinteresēti šìs sociālo pakalpojumu lietotāju kategorijas dzīves kvalitātes uzlabošanā, kā arī citus cilvēkus ar līdzīgu pieredzi. Par mugursomas metodi to sauc tādēl, ka pats pirmais jautājums, kas bēgliem parasti tiek uzdots, ir jautājums "Kas bija jūsu mugursomā, ko paņēmāt līdzi no mājām?”. Bēglus var lūgt parādīt kādu no šīm lietām vai izstāstīt par tām, ja vini to vēlas. No dzimtām vietām līdzi ņemtais var būt ne vien materiālas lietas, ko var parādìt, bet arī kaut kas simbolisks vai kāda ideja. Mugursoma ir drīzāk iztēles ideja par sev nozīmīgo vērtību krātuvi, nevis reāla soma. Nākamie jautājumi, kas seko pirmajam, ir: "Ko jūs šodien liktu savā mugursomā? Kas mugursomas saturam ir nācis klāt? Kas jums šobrīd ir nozīmīgs?” Pēc atbildēm uz šiem jautājumiem seko ieskatīšanās nākotnē. Bēgliem tiek uzdoti jautājumi par to, ko, vinuprāt, nākotnei noderīgu vajadzētu ielikt savā mugursomā. "Kas jūs būsiet pēc pieciem vai desmit gadiem? Kas kavē realizēt jūsu ieceres?” - ir turpmākie jautājumi. Tad kopā ar citiem darba grupas dalībniekiem, balstoties uz atbildēm par šiem jautājumiem, tiek iezīmēta vēlamā nākotnes perspektīva un tās sasniegšanai nepieciešamās 
darbības. Šajā metodē ḷoti svarīga ir pakalpojumu lietotāju iesaistī̌̌anās un vēlme lỉdzdarboties. N̦emot vērā iespējamās valodas barjeras, sekmīgam dialogam var būt nepieciešams tulks. Vizuālas metodes var palīdzēt attēlot tagadējo un nākotnes saturu, kas ņemts līdzi mugursomā.

\subsection{Nākotnes darbnīca (future workshop)}

Nākotnes darbnīca ir viena no SEMPRE projekta Zviedrijas partnera lietotajām metodēm. Tā ir grupas intervija ar mērkgrupas pārstāvjiem - sociālo pakalpojumu galalietotājiem. Metode sastāv no trīs secīgiem posmiem jeb fāzēm. Pirmā ir kritiskā fāze, otrā - fantāzijas fāze un trešā ir isstenošanas fāze.

Kritiskās fāzes laikā intervijas dalībnieki izsaka savas bažas, stāsta par sarežǵījumiem savā dzīvē, viṇu pašreizējās problēmsituācijas izraisa "prāta vētru". Tāpēc tiek skaidri formulētas vairākas problēmas, kas skar visus grupas intervijas dalïbniekus. Problēmas ieteicams uzrakstìt uz tāfeles vai uz līmlapām, kas novietojamas dalībniekiem redzamā vietā.

Fantāzijas fāze ir iespēja attīstīt vīziju par to, kāda būtu labāka pasaule. Pirmajā fāzē izteiktā kritika tiek mainīta pret pozitīvām idejām un ieteikumiem. Idejas tiek apspriestas un attīstìtas, ja nepieciešams, darbojoties mazākās grupās.

İstenošanas fāzē notiek kopīga diskusija par fantāzijas fāzē izstrādātajām vīzijām. Te būtiski apspriest praktiskos soḷus, kas ḷautu tuvināties šo vīziju realizācijai, izstrādāt rīcības plānu, pārrunāt konkrētas ieteicamās rīcības. Ideāls variants ir tāds, kurā kopīgo sadarbību var turpināt, koordinējot un realizējot nākotnes darbnīcā veidoto rīcības plānu. Zviedrijas partneri izmanto tikai šis metodes pirmo - kritisko fāzi, lai izzinātu aktuālās problēmas un vajadzības. Viṇi uzsver, ka liela nozīme ir nākotnes darbnīcas vadītājam. Viņa ziņā ir veidot labu atklātības un kopīgas diskusijas atmosfēru šai darbnīcā.

Nākotnes darbnīcas metode tika dalieji izmēgināta divās grupas intervijās Liepājā. Vienreiz nākotnes darbnīca tika organizēta telpās personām ar invaliditāti, kas regulāri satiekas. Otrā nākotnes darbnīca bija domāta personām ar invaliditāti, kas iepriekš nav sadarbojušās, un tā notika vasarā dārzā pie Liepājas Mākslas muzeja. Atklātība un aktīva interese izstāstìt savu stāstu bija raksturīga abām nākotnes darbnīcām. Ievērojami vieglāk bija strādāt ar tiem, kas iepriekš bija tikušies un 
pieraduši kopīgi darboties, jo arī grupas darbs prasa iemaņas, kas jāizkopj. Grupā, kuras locekḷi nebija iepriekš tikušies, dominēja individuālāks diskurss, katrs vairāk stāstīia nekā uzklausīja. Arī nākotnes darbnīcas vadītāja ar šo grupu darbojās pirmo reizi. Secinājums ir tāds, ka vieglāk organizēt diskusiju un orientēties uz konkrētiem uzdevumiem bija nākotnes darbnīcā, kas notika telpās.

\subsection{Logiskās strukturēšanas pieeja (logical framework approach)}

Logiskās strukturēšanas pieeja ir deviṇu soḷu metode. Pirmais solis ir projekta konteksta analīze. Otrais solis ir iesaistìto un ieinteresēto pušu (stakeholders) analīze. Trešais solis - problēmas analīze. Ceturtais solis - mērķu analīze. Piektais solis - aktivitāšu plāna izstrāde. Sestais solis - resursu ieguves plāna izstrāde. Septītais solis - indikatoru noteikšana. Astotais solis - risku analīze. Devitais solis ir pieñēmumu analīze. Vajadzību apzināšana notiek pirmajos trīs soḷos. Projekta konteksta un iesaistìto pušu analīze ir priekšdarbi, ko var veikt nelielā darba grupā. Tie veido kontekstu trešajam solim. Problēmas analīze notiek kopā ar pakalpojumu galalietotājiem un iesaistītajām un ieinteresētajām pusēm, iegūstot pēc iespējas dažādākus skatījumus uz problēmu. Vispirms problēma ir jādefinē. Te SEMPRE projekta Zviedrijas partneri kā piemēru min iedzìvotāju skaita samazināšanos lauku regionos. Nākamais solis ir strukturēt cēloṇus un sekas, ko var attēlot kā koku, kam saknes ir problēmas cēloṇi, stumbrs - pati problēma, bet zari ir problēmas sekas. Lai to paveiktu, diskusijas dalībnieki sadalās divās grupās, kur viena grupa apkopo idejas par cēloṇiem, otra - par sekām. Cēloṇi minētajā piemērā par iedzīvotāju skaita samazināšanos laukos ir, piemēram, darbavietu trūkums un infrastruktūras nepietiekamība. Savukārt šì procesa sekas ir mazāki nodokḷu ieņēmumi reǵiona pašvaldībā, spējīgāko un gudrāko kopienas pārstāvju aizbraukšana. Katru ideju uzraksta uz atsevišķas līmlapas. Cēloṇu līmlapas salīmē pie saknēm, bet seku lapas pie zariem, izveidojot "problēmas koku". Tas palīdz vizualizēt, kā lietas ir saistītas, un iegūt labāku priekšstatu par situāciju kopumā. Lai novērstu nevēlamas sekas, ir jārisina tie jautājumi, kas ir seku cēloṇi.

Mērḳu analīze notiek līdzīgi, skatot to struktūru kā "mērḳa koku", kur saknes ir darbības, kas nepieciešamas, lai sasniegtu mērķi, bet zari ir pārmaiņas, ko mērķa sasniegšana var dot. Zviedrijas partneri atzīmē, 
ka grūtākais šajā pieejā ir panākt visu pušu aktīvu līdzdalību viedokḷu un ideju paušanā. Vieglāk ir panākt iesaistǐšanu trešajā solī, ja dalībnieki jau tikuši iesaistīti plānošanas procesā vai ir strādājuši kopā ar kādu no vadītājiem. Dažkārt var būt nepieciešams problēmu analizēt vispirms atseviški ar sociālo pakalpojumu galalietotājiem, lai viṇus iedrošinātu paust domas un idejas grupā kopāa ar citiem.

\section{Labas prakses piemēri sociālo pakalpojumu galalietotāju iesaistīšanā}

Pilsoṇu iesaistǐšana un iesaistī̌̌anās kopīgās sociālās dzīves veidošanā un norisēs ir demokrātiskas sabiedrības pazìme.

2017. gada oktobrī SEMPRE projekta partneri tika aicināti savstarpēji dalīties ar reāliem piemēriem, kā vinu valstī līdz šim ir tikusi realizēta sociālo pakalpojumu saṇēmēju iesaiste konkrētu sociālo pakalpojumu sniegšanā un spēcināšanas procesā kopumā. Aicinājuma mērḳis bija apkopot praktiskas pieredzes stāstus, lai iedrošinātu un iedvesmotu citus. Rezultātā septiṇi projekta partneri atsūtīja informāciju par savām aktivitātēm. Šeit apkopots neliels ieskats iesaistišanas un iesaistǐšanās un sociālās spēcināšanas aktivitāšu dažādībā. Piemērs no Igaunijas ir aktivitāte, kas veikta SEMPRE projekta ietvaros. Seši citi partneri (trīs no Vācijas, pa vienam no Dānijas, Somijas un Latvijas) te aprakstīto labo praksi ir realizējuši citos projektos.

\subsection{MarktTreff (Vācija)}

MarktTreff ir vācu valodas saliktenis. Tajā der Markt nozīmē 'tirgus', der Treff - 'satikšanās'. MarktTreff ir sadarbības tìkls, kas jau 17 gadus darbojas Šlēsvigas-Holšteinas federālajā zemē Vācijas ziemelıos. Tā mērḳis ir nodrošināt dažādu pakalpojumu pieejamību lauku reǵionos. MarktTreff ir savdabīga, speciāli veidota tirgus vieta, kur vienkopus atrodamas gan preces un pakalpojumi, gan informācija, idejas un iniciatīvas. Tā rada iespēju koncentrēt vienuviet dažādos piedāvājumus, kā arī rada darbavietas, nodrošina informācijas apriti un kalpo kā kopienu spēcinoša aktivitāte. MarktTreff ir satikšanās punkts. Tas ir mūsdienīgs tirgus, kur līdztekus ierastajām precēm tiek 
piedāvāta, piemēram, interešu izglìtība, veselības aprūpes pakalpojumi, kur ir iespējams uzlādēt vai salabot mobilo telefonu. Te ir pieejami kurpnieka, friziera, vel̦as mazgātavas, bankas vai pasta pakalpojumi un notiek interesanti pasākumi, kuros var pavadìt brīvo laiku un satikt līdzcilvēkus. Tieši MarktTreff dzīvīgums un plašā iespēju un piedāvājumu dažādība ir lielākais ieguvums, ko šis sociālais tirgus sniedz kopienām lauku regionos.

Šlēsvigas-Holšteinas federālajā zemē 2017. gada oktobrī darbojās 38 MarktTreff vietas. Tiek plānots to skaitu palielināt līdz 50. Katra vieta ir atšķirīga un atbilst konkrētās kopienas interesēm un vajadzībām. Kopienas iedzīvotāji to vērtē kā pozitīvu iniciatīvu, kas uzlabo viņu dzīves kvalitāti. MarktTreff iniciatore bija Šlēsvigas-Holšteinas federālās zemes valdība, kas sabiedrībā aktīvi veicināja sadarbību, aicināja biznesa sektoru un dažāda profila nevalstiskās organizācijas iesaistīties projekta attīstībā. Katras MarktTreff vietas mērķis ir tās ekonomiska ilgtspēja. To lielā mērā nodrošina pārtikas veikals, kas ir galvenā uzṇēmējdarbības forma šajās vietās.

\subsection{Prasmju kalve (Dānija)}

Prasmju kalve ir projekts, kas no 2012. līdz 2016. gadam tika īstenots Fredericijā (Fredericia), Dānijā. Tā ietvaros cilvēki ar garīgās attīstỉbas traucējumiem (persons with learning disabilities) tika mācīti par mentoriem, lai viṇi varētu palīdzēt citiem cilvēkiem ar garīgās attīstības traucējumiem apgūt ikdienā noderīgas prasmes un iemaņas. Projekta gaitā līdzās apgūtajām prasmēm būtisks blakus ieguvums ir mācību un mācǐšanas procesa pozitīvais iespaids uz dalībnieku pašapziņu un prieks par panākumiem. Projekta mērkis bija paplašināt skatijumu uz mentora lomu, l̦aujot palūkoties uz to kā uz daudzpusīgu un vienojošu praksi kopā ar cilvēkiem, kam ir garīgās attīstības traucējumi.

Par vietējiem prasmju kalves centriem tika izraudzìtas četras vietas - nodarbinātības centrs, divas sociālās mājas un viena kafejnīca, kas ir tikšanās vieta tām personām ar garīgās attīstības traucējumiem, kuras dzīvo patstāvīgi. Katrā prasmju kalves centrā tika iesaistīti divi darbinieki, kas jau strādāja uz vietas, kā arī izraudzìtas divas vai trīs personas ar garīgās attīstības traucējumiem, lai viņus mācìtu par mentoriem. Mācītie mentori, profesionālo darbinieku atbalstīti, palīdzēja attīstīt noderīgas iemaņas citām personām ar garīgās attīstības 
traucējumiem. Tà tika apgūta, piemēram, kafijas pagatavošana bez citu palīdzības. Prasmju kalvju centru dalībnieki, tiekoties reizi mēnesī, veidoja kopīgu sadarbības tìklu, lai pārrunātu līdzšinējo pieredzi un turpmākās aktivitātes.

Projektu atbalstīja vietējā pašvaldība, Attīstības asociācija (Udviklingshæmmedes Landsforbund, ULF) un Dānijas personu ar garīgās attīstības traucējumiem savienība. Attīstības asociācijas mērḳis ir padarīt redzamu dažādo cilvēku pieredzi un stāstus, veidot iekḷaujošu sabiedrību. Prasmju kalves projekts beidzās 2016. gadā, kad pašvaldībā tika veiktas organizatoriskas pārmainas. Projekts bija atkarīgs no tajā iesaistīto cilvēku intereses uzlabot šìs sociālo pakalpojumu lietotāju kategorijas dzīves apstākḷus un no vinu nesavtīguma. Administratīvās reformas izraisītā nestabilitāte projekta darbībai nebija labvēlīga. Attīstības asociācijas paspārnē tika dibināta atbalsta grupa, lai turpinātu projekta iestrādnes pēc 2016. gada, kad projekta finansējums beidzās.

\subsection{ICT-Café (Somija)}

ICT-Café ir aktivitāte, kuru Somijā kopš 2015. gada organizē Korsholmas (Korsholm/Mustasaari) zviedriski runājošo pensionāru asociācija. ICT-Café seniori ar dažāda līmeņa informācijas un komunikācijas tehnolog̣iju zināšanām atbalsta un māca citus seniorus, kas ir mazāk prasmīgi informācijas un komunikācijas tehnologiiju lietotāji. ICT-Café apmeklētāji, savstarpēji cits citam palīdzot, apgūst dažādu ikdienā noderīgu digitālo aplikāciju izmantošanas prasmes, iemācās izveidot profilu sociālajā medijā Facebook, apgūst un izmēǵina pieeju banku un veselības pakalpojumiem tiešsaitē. ICT-Café var piedalīties ikviens, iepriekšēja reğistrācija nav nepieciešama. Katras kopā sanākšanas saturu nosaka paši dalībnieki. ICT-Café ir guvusi plašu atsaucību.

ICT-Café panākumi balstās uz idejas vienkāršību un reālo nepieciešamību vecāka gadagājuma cilvēkiem apgūt informācijas un komunikācijas tehnologiju prasmes un tās lietot. Viṇi sanāk kopā, iepriekš vienojoties par tikšanās laiku. Kafija un draudzīgā atmosfēra palīdz veidot piederības sajūtu un iedrošina iesaistīties. Iedrošinājums un atbalsts ir būtisks, jo ir tādi seniori, kas baidās kḷūdīties, jūt nedrošỉbu, lietojot informācijas un komunikācijas tehnologiijas. Tas, ka vecāka gadagājuma cilvēki māca citus seniorus, palīdz veidot labāku savstarpējo kontaktu un atrast piemērotus un saprotamus veidus, kā paskaidrot 
interesējošo tēmu. Pēc regulāriem apmeklējumiem vairāki dalībnieki ir patiesi ieinteresēti iegūt zināšanas un turpina mācības augstākas sarežgîitības informācijas un komunikācijas tehnoloğiju kursos.

\subsection{Domu fabrika (Vācija)}

Domu fabrika (Denkfabrik - vācu valodas saliktenis, kurā vārds denken nozīmē 'domāt', die Fabrik - 'fabrika') ir mazāk aizsargāto sociālo grupu forums. Tas darbojas Štutgartē, Vācijā, sociālā uzṇēmuma "Jaunais darbs" (Sozialunternehmen Neue Arbeit GmbH) paspārnē. Viens no Domu fabrikas darbības virzieniem ir pētniecība, kas veidota kā spēcinoša un iesaistoša aktivitāte šai mērḳgrupai.

Veiksmīgs Domu fabrikas līdzdalības pētijuma piemērs ir darbs ar ilgstošiem bezdarbniekiem, kuri ir politiski pasīvi un nepiedalās vēlēšanās. Veikt pētījumu rosināja novērojums, ka vēlēšanās mazāk aktīvi ir cilvēki ar zemākiem ienākumiem. Ilgstošie bezdarbnieki ir plaši pārstāvēti zemo ienākumu grupā. Viņi no paša sākuma tika iesaistīti pētījuma procesā un piedalījās interviju jautājumu izstrādē, intervēšanas procesā un veiktā pētījuma novērtēšanā. Pētījuma empīrisko datubāzi veidoja 70 intervijas. Mērḳgrupas iesaistī̌sana visos pētījuma posmos nodrošināja to, ka socioloǵisku datu, analīzes un pārskatu kopumā netika pazaudēta cilvēku individuālā pieredze un dzīves gājums. Papildus intervijām mērķgrupas pārstāvji savu pieredzi dokumentēja fotogrāfijās un attēlos. Rezultātā tapa emocionāli uzrunājošs materiāls, kas jau ir apceḷojis trīs izstāžu vietas. Pēc pētỉjuma publicēšanas un tā prezentācijām vairākās konferencēs mērkgrupas pārstāvjiem tika sarīkota diskusija ar politikas veidotājiem. Aktīvā iesaistǐšanās un informācija par pētījumu deva pārliecību, ka viṇu viedoklis ir nozīmīgs un vinuu iesaistī̌sanās politikas procesos var tās veidošanu ietekmèt.

Domu fabriku atbalsta Bādenes-Virtembergas federālās zemes valdība, federāā programma "Sociāla līdzdalība darba tirgū", Federālā nodarbinātības un sociālo lietu ministrija, Štutgartes Nodarbinātības dienests un Nacionālā loto loterija.

\section{5. "Latvijas Kustība par neatkarīgu dzīvi” (Latvija)}

Biedrība "Latvijas Kustība par neatkarīgu dzīvi” pārstāv personu ar invaliditāti intereses un vajadzības. Biedrības mērḳis ir veicināt 
iekḷaujošas sabiedrības attīstību un nodrošināt vienlīdzīgas iespējas ikvienam sabiedrības loceklim. Īpaša uzmanība tiek pievērsta tam, lai sasniegtu cilvēkus ar garīgās attīstības traucējumiem un multiinvaliditāti. Biedrība ir dibināta 2009. gadā. Sākotnēji bija tikai neformālas tikšanās ar personām, kam ir invaliditāte, un informācijas apmaiņa ar viņiem un viṇu tuviniekiem. Kopš 2013. gada šì biedrība ir Eiropas Sociālo pakalpojumu sniedzēju personām ar invaliditāti asociācijas (European Association of Service Providers for Persons with Disabilities, EASPD) biedre. Biedrība "Latvijas Kustība par neatkarīgu dzīvi" ir piemērs tam, kā no nelielas iniciatīvas izaug organizācija, kas ir nozīmīgs sociālais partneris politikas procesos un lēmumu pieņemšanā.

Biedrība piedāvā dienas centra pakalpojumus bērniem ar invaliditāti, ir izveidojusi atbalsta grupas vecākiem un aprūpētājiem, organizē kopīgu dzīves telpu - grupu dzīvokḷus personām ar garīgās attīstības traucējumiem, uztur atbalsta darbnīcas. Viena no atbalsta darbnīcu aktivitātēm ir sveču liešana. Tajā piedalās biedrības dienas centra apmeklētāji - personas ar dažādiem garīgās attīstības traucējumiem. Kopīgi darbojoties, viņiem ir iespējams socializēties, un veidošanas un radī̌sanas process stiprina viṇu pašapziņu un ḷauj justies noderīgiem. Šobrīd sveču liešanas aktivitāte, kas aizsākās interešu grupā, ir attīstījusies un ir radīts sociāls uzṇēmums.

\section{6. (Dārz)kopība (Vācija)}

Šì projekta oriğinālais nosaukums ir G(a)arden(ing). Nosaukums ir veidots kā vārdu spēle, kas sapludina angḷu valodas vārdu gardening 'dārzkopība' un K̦iles rajona Gaarden nosaukumu. G(a)arden(ing) ir dārzkopības projekts Vācijā. Projekts norisinājās no 2013. līdz 2016. gadam, dārza izveidē iesaistot bērnus un jauniešus, it sevišķi no mazāk aizsargātām sociālām grupām. Jaunieši tika iesaistīti teritorijas plāna izveidē, teritorijas sakopšanā, dobju veidošanā, sēšanā, stādī̌anā, ravēšanā, laistǐšanā un ražas novākšanā un sadališsanā projekta noslēgumā. Lai īstenotu ekoloǵisku pieeju, dārza izveidē tika izmantoti tikai pārstrādājami un atkārtoti izmantojami materiāli. Projekta mērḳis bija veicināt gados jauno migrantu, it sevišḳi marginalizēto romu un sintu, integrāciju sabiedrībā. Kopīgā darbā un komunikācijā, kurā piedalījās arī vietējie iedzīvotāji, veidojās jauniešu imigrantu sociālais kapitāls un spēcināšanas izjūta. 
Projekta iniciatore bija profesore no Ķiles augstskolas (Kiel University of Applied Sciences, Fachhochschule Kiel - Hochschule für Angewandte Wissenschaften), kas ideju aizguva no citiem sociālās dārzkopības projektiem Vācijā. Projekta G(a)aden(ing) realizācijā aktīvi iesaistijās augstskolas pedagogiijas studenti. Projektu atbalstija Ķīles pašvaldība un viena nevalstiskā organizācija. Ķīles pašvaldība projekta realizācijai ierādīja zemes gabalu, kas pieder pilsētai. Projekta G(a)rden(ing) devumu sociālās integrācijas procesā nodrošināja mijiedarbība ar vietējiem iedzīvotājiem un augstskolas studentiem, visus bagātinot ar jaunu savstarpējās mijiedarbības pieredzi.

\subsection{Filca bumbas stresa mazināšanai (Igaunija)}

Vienu no pirmajiem mikroprojektiem SEMPRE projekta ietvaros realizēja partneri no Igaunijas Evaņgéliski luteriskās baznīcas, kas atrodas un aktīvi darbojas Harkujerves ciemā. SEMPRE projektā šī mikroprojekta mērḳis ir spēcināt cilvēkus, kam ir invaliditāte, it sevišḳi gimenes ar bērniem, kam ir invaliditāte.

Mikroprojekta aizsākumu rosināja informācija, ko uzzināja kopīgās sarunās ar mērksgrupas pārstāvjiem, proti, ka daži vecāki saviem bērniem ir noadijjuši nelielas bumbas ar mîkstu pildījumu. Bērniem patīk ņurcīt šìs pašdarinātās bumbas, un tās ietekmē bērnus kā stresu mazinošs līdzeklis. Mazinās trauksmes sajūta un iekšējs sasprindzinājums. Mīkstās, elastīgās bumbas, tās turot plaukstās, kairina receptorus un tā palīdz nomierināties un koncentrēties.

Igaunijas Evaṇgéliski luteriskās baznīcas pārstāvji organizēja mācības un darbnīcu, kur jauni cilvēki ar garīgās attīstības traucējumiem iemācījās izgatavot līdzīgas bumbas no filca. Gatavais produkts tālāk tika nodots bērniem ar invaliditāti, kā arī tirgots labdarības tirdziņā, kur tās ieguva lielu atsaucību un labi pirka.

Filca bumbu izgatavošanas pulciņa izveide palīdzēja gan bērniem ar invaliditāti, kas ieguva papildu līdzekli trauksmes sajūtas mazināšanai, gan tiem cilvēkiem ar garīgās attīstības traucējumiem, kuri apguva jaunu prasmi, guva kopigas darbošanās prieku un gandarījumu par paveikto.

Šobrīd Harkujerves Evaņgéliski luteriskā baznīca nodrošina septiņu dažādu radošo pulciņu darbību, arī teātra un dejas nodarbības. Ar domubiedru atbalstu un palīdzību ir sakopta teritorija ap baznīcu un iekopts dārzs. 
Labas prakses piemēri sociālo pakalpojuma lietotāju iesaistī̌nanai sociālo pakalpojumu sniegšanā un spēcināšanas procesā kopumā, ko piedāvā SEMPRE projekta partneri, rāda dažādas iespējas, kā domāt par spēcināšanu un iesaistī̌sanu un iesaistī̌šnos. Visos mikroprojektos tiek veicināta cilvēku savstarpējā komunikācija, kas var būt gan informācijas apmaiṇa, gan kopīga jaunu prasmju apgūšana vai kopīga darbu veikšana.

\subsection{Mikroprojekti, kas SEMPRE projekta ietvaros īstenoti Kurzemes regionā ${ }^{1}$}

Liepājas Diakonijas centrs kā SEMPRE projekta partneris Kurzemes regiionā ir ierosinājis īstenot piecus mikroprojektus. Mikroprojekti ir iecerēti un apspriesti sadarbībā ar novadu sociālajiem dienestiem, personām ar invaliditāti un citām iesaistītajām un ieinteresētajām pusēm. Atbilstoši SEMPRE projekta idejai veicināt sociālu spēcināšanu lauku regionos mikroprojekti tiek realizēti nevis Liepājā, bet Kurzemes regiona lauku iedzivotājiem novadu un pagastu centros Grobiņā, Bārtā, Dubeņos, Rucavā un Durbē. Mikroprojekti ir plānoti, pārrunāti, aizsākti un attīstìti, kopīgi darbojoties vietējos sadarbības tīklos.

Saskan̄ā ar Liepājas Diakonijas centra pārstāvju Mārtiṇa Urdzes un Karīnas Krievinasas sniegto informāciju SEMPRE projekta ietvaros Kurzemes regionā no 2016. līdz 2019. gadam tiek īstenoti pieci mikroprojekti. To īstenošanas vietas ir Grobiṇa, Bārta, Dubeṇi, Rucava un Durbe.

Grobiṇā labiekārto Tikšanās dārzu personām ar invaliditāti, kur varētu satikties un kopīgi nodarboties ar dārza darbiem, rīkot nelielus pasākumus, būt kopā ērti pieejamā un sakoptā vidē. Projekta ietvaros izveidota atbalsta grupa "Kopā būt", kurā kopā ar personām ar invaliditāti aktīvi darbojas arī Sarkanā Krusta organizācija un tās Grobiṇas nodaḷas personāls, Grobiṇas novada Sociālais dienests, Grobiṇas Evaṇgêeliski luteriskās baznīcas diakonija, kā arī citu iesaistīto un ieinteresēto pušu pārstāvji. Šis mikroprojekts risina tādas personu

Informāciju par mikroprojektu īstenošanu Kurzemes regionā snieguši Karīna Krieviṇa un Mārtiņš Urdze (A. S.). 
ar invaliditāti vajadzības kā nepieciešamība pēc pozitīviem sociāliem kontaktiem un jēgpilnas laika pavadīšanas.

Projekta izpildes sākumstadijā 2017. gada maijā ar pašvaldību tika risināts jautājums par aț̣auju izmantot zemes gabalu līdzās Sarkanā Krusta èkai. Nākamais uzdevums ir sarīkot puḳu stādu un krūmu stādu dāvināšanas pasākumu.

Bārtā tiek veidota Baskāju taka, kam materiāli sarūpēti kopīgos izbraukumos un talkās. Tie ir oḷi, akmeņi, koka ripiņas, zīles, kastaņi, šķelda. Ar Bārtas pagasta Sociālā dienesta palīdzību uzrakstīts projekts pašvaldības atbalsta pasākumiem. Projektā kopā ar Grobiṇas novada personām ar invaliditāti līdzdarbojas pašvaldības Sociālais dienests, Bārtas pagasta pārvalde, Bārtas kultūras nams, ir cieša sadarbība ar Grobiṇas novada atbalsta grupu "Kopā būt". Arī šajā mikroprojektā tiek radīta iespēja pozitīvu sociālo kontaktu uzturēšanai un jēgpilnai laika pavadī̌sanai.

Projekta izpildes sākumstadijā 2017. gada maijā notiek pārrunas ar pašvaldību par vietu, kur Baskāju taka varētu tikt izveidota, tiek plānoti komunikācijas pasākumi, lai pievērstu sabiedrības uzmanību šim projektam.

Grobiñas novada Dubeños mikroprojekta uzdevums ir iekārtot vienkāršu uzbrauktuvi pie daudzdzīvokḷu nama ieejas, tā risinot vides pieejamības jautājumu. Šai namā ir atvēlētas telpas lūgšanu kapelai un atbalsta grupas tikšanās vietai. Pie nama ieejas ir pakāpieni, kas apgrūtina vides pieejamību cilvēkiem ratiņkrēslos. Šajā gadijjumā uzmanība ir vērsta uz vajadzību patstāvīgi pārvietoties telpā, tātad uz vides pieejamību, kas ir nozìmīga komponente citu vajadzību apmierināšanai.

Mikroprojekta izpilde sākusies 2017. gada maijā, izveidojot tā īstenošanas plānu un nosakot soḷu secību tā īstenošanai.

Rucavā personu ar invaliditāti atbalsta grupa "Cerību stariņš" veido recepšu krājumu vienkāršu, lētu un garšīgu èdienu pagatavošanai. Mikroprojekta dalībnieki paši gatavo èdienus, izmantojot produktus no Eiropas Savienības pārtikas pakām, kas domātas trūcīgiem cilvēkiem, kā arī citus ikdienā pieejamus produktus. Receptes tiek apspriestas un pierakstītas, lai tās apkopotu un publicētu. Šāds recepšu krājums būs noderīgs arī citām atbalsta grupām un interesentiem, kas ir līdzīgā trūcīgo un maznodrošināto personu statusā. No vienas puses, šis mikroprojekts palīdz apmierināt pamatvajadzību pēc èdiena ierobežotu resursu apstākḷıs. No otras puses, tas apmierina vajadzību pēc 
pozitīviem sociāliem kontaktiem, jaunrades un kopā būšanas. Rucavas novada Sociālais dienests aktīi līdzdarbojas šai mikroprojektā no paša atbalsta grupas veidošanas pirmsākuma.

2017. gada maijā mikroprojektā tiek kopīgi izmēǵinātas un pierakstītas receptes, lai sakopoto krājumu publicētu brošūrā. Mikroprojekta dalībnieki - personas ar invaliditāti - ir l̦oti apmierinātas ar šo kopdarbošanos.

Durbē mikroprojekta ietvaros veido mācību kursu un organizē mācības brīvprātīgajiem asistentiem, kas palīdzētu personām ar invaliditāti tikt galā ar dažādām lietām. Mācībās ir iekḷautas dažādas praktiskas un teorētiskas nodarbības, kas to dalïbniekiem dod iespēju palīdzēt citiem, strādājot par asistentiem. Mācību programmā ir iekḷauts pirmās palīdzības kurss, sociālās likumdošanas kurss par personu ar invaliditāti tiesībām un pienākumiem, fizioterapeita konsultācija, nodarbības par saskarsmes psiholog̣ijas tematiem. Ir oficiāli reǵistrēta Durbes atbalsta biedrība personām ar invaliditāti, to sauc "Roku rokā". Šajā mikroprojektā vajadzība attīstīties un jēgpilni pavadìt laiku tiek risināta līdztekus vajadzībai pēc palīdzības un sociāliem kontaktiem.

Mikroprojektā plānotās nodarbības ir uzsāktas 2017. gada maijā. Durbes pašvaldība ir solījusi sniegt atbalstu ar transportu. Lìdzekḷi degvielas iegādei ir jāmeklē. Ir iecere, ka pēc mācību beigšanas katrs to dalībnieks atrod aprūpējamo, kam palīdzēt. Turpmākais atbalsts dalībniekiem plānots supervīziju veidā.

Sākotnēji Kurzemes reǵionā tika plānots attīstìt pa vienam mikroprojektam Grobiṇā, Rucavā un Priekulē. Visos trīs novados ir izveidojusies laba sadarbība ar sociālajiem dienestiem. Sadarbỉbas tīklam attīstoties, Grobiṇas novadā radās trīs atbalsta grupas - Grobiṇā, Bārtā un Dubeņos. Redzot sociālo pakalpojumu galalietotāju un citu iesaistīto pušu ieinteresētību un reālās vajadzības, mikroprojektu programmu šeit tika nolemts paplašināt. Tā kā atbalsta grupas Bārtā un Dubeņos izveidojās vēlāk, tad arī projektu izpilde tur ir agrīnākā stadijā. Savukārt Priekules atbalsta grupa turpina darboties jau šobrīd piedāvātajos pašvaldības pasākumos, kā arī aktīivi iesaistās SEMPRE projekta sadarbības tīkla sapulcēs un pasākumos, mikroprojektam atvēlētos līdzekḷus atstājot jaunizveidoto atbalsta grupu plānotajiem pasākumiem. Šādai elastīgai pieejai ir lielāks kopējais ieguvums, kā arī tā stiprina sadarbības saites starp atbalsta grupām. 
SEMPRE projekta mērḳis ir palīdzēt sociālo pakalpojumu sniedzējiem attīstīt mūsdienīgus sociālos pakalpojumus. Sociālo pakalpojumu galalietotāju spēcināšana, iesaistīšana un iesaistîšanās ir nozīmīgi mūsdienīgu sociālo pakalpojumu izveides faktori. Tie ne tikai veicina konkrētā uzdevuma izpildi vai pakalpojuma radīšanu, bet arī sniedz iemaņas citu problēmsituāciju risināšanai un pakalpojumu galalietotājiem dod pārliecību par pašu iesaistī̌anās svarīgumu. Vietējo sadarbỉbas tîklu veidošana un sadarbïbas praktizēšana ir viens no atbalsta pasākumiem, ko Liepājas Diakonijas centram ir izdevies realizēt. Mārtiņš Urdze un Karīna Krieviña uzsver, ka tas ir laikietilpīgs process, kas prasa pacietību un iejūtību: "Vajadzīgs laiks, lai viens ar otru iepazìtos, atklāti dalītos ar savām vajadzībām un problēmām, kopīgi meklētu risinājumus, kā atbalstīt vienam otru, izmantojot tos resursus, kas ir pieejami konkrētajā vietā.”

Kurzemes regiona mikroprojekti ir veidoti un attīstīti, skrupulozi sekojot idejai par sociālo pakalpojumu sniedzēju, galalietotāju un citu iesaistīto un ieinteresēto pušu kopdarbošanos. Idejas par mikroprojektiem netika pasniegtas gatavas. Tās meklētas un pārrunātas sadarbības tỉklu sapulcēs. Tika veidota vide, kur rasties un attīstīties mikroprojektu idejām. Tā ir atzinīgi vērtējama iesaistī̌sanas un spēcināšanas prakse, kurā mikroprojektu idejas un iniciatīvas tika pacietīgi meklētas un izaudzētas jaunizveidotajos vietējos sadarbības tỉklos. Tas ir prasījis daudz laika, tādēḷ mikroprojektu realizēšana nenotiek tik ātri, kā sākotnēji plānots. Tā kā SEMPRE projekta galvenais mērḳis ir sociālo pakalpojumu sniedzēju spēcināšana, lai viṇi spēcināšanu pārnestu uz sociālo pakalpojumu galalietotājiem, tad mikroprojekti ir rīki, kas to palīdz ìstenot. Šādā kontekstā ir uzteicama projekta partnera - Liepājas Diakonijas centra - pacietība un neatlaidỉba. Visi pieci mikroprojekti vērtējami kā SEMPRE projekta idejai un mērḳiem atbilstoši.

Nākotnē plānojot šādus uz sociālo iesaistî̌sanu un spēcināšanu balstītus projektus, jāṇem vērā, ka sociālo pakalpojumu galalietotāju sasniegšana un iesaistī̌sana aktivitātēs, tāpat kā kopīgas sadarbības veidošana iesaistìto un ieinteresēto pušu starpā, ir laikietilpīgs process. Tomēr tieši pats process ir būtiska spēcināšanas komponente. Ideju meklēšana un attīstī̌̌ana atbalsta grupās, kas jau ir ne tikai iesaistī̌̌ana, bet arī pašu dalībnieku iesaistǐšanās, savukārt, dod lielāku ticamību mikroprojektu ilgtspējai un atbalsta grupu aktivitāšu turpinājumam pēc SEMPRE projekta noslēguma. 


\section{Divpadsmit mikroprojekti SEMPRE projekta partnerības ${ }^{2}$ valstīs (īstenoti līdz 2018. gada jūlijam)}

\section{1. Šlēsvigas-Holšteinas diakonija (Vācija)}

Šlēsvigas-Holšteinas diakonijas darbinieki ir îstenojusi trīs mikroprojektus.

Pirmais mikroprojekts ir tīmekḷa vietnes izveidošana viena vecāka goimenēm. Tā ir nosaukta par AllDi. Tās mērḳis ir piedāvāt noderīgas informācijas klāstu, iespēju sadarboties, komunicēt un kooperēties viena vecāka ğimenēm. Tiek veidota organizācija, kas nodrošinātu vietnes darbību un aktuālās informācijas plūsmu, kā arī veidotu kodolu komandas darbam kopā ar sociālo pakalpojumu sniedzējiem. Vecāku atsaucība un interese apgūt jaunas iemaņas un zināšanas ir negaidīti liela. Sākumā sociālo pakalpojumu sniedzējiem trūka entuziasma, šobrīd visi projekta dalībnieki ir ieinteresēti un aktīvi iesaistījušies. Procesā ir nācies saskarties ar aizspriedumiem gan par projekta iniciatīvām, gan par viena vecāka gimenēm. Pirms šì mikroprojekta pastāvēja interneta vietne viena vecāka ğimenēm reǵionā. Tā kā informācija tajā netika atjaunota, tā bija zaudējusi aktualitāti. Šobrīd vecāki paši kopīgā darba grupā veido vietni, kas atbilstu viṇu vajadzībām. Šãda mikroprojekta attīstǐšana prasa daudz laika. Spēcināšana ir laikietilpīgs process, kur nepieciešama liela pacietỉba, tādēḷ būtiski ieplānot pietiekami daudz laika gan idejas realizācijai, gan attīstībai.

Otro mikroprojektu sauc “"Veselības tīkls" viena vecāka gimenēm” ("health network" for single parents). Veselības tìkla mērḳis ir rūpēties par veselību, mazināt stresu ikdienas rutīnā un laika trūkumā, veicināt sociālo mijiedarbību, sniegt atbalstu pašaprūpei un organizēt sociālās sadarbības tīklu, piemēram, jogas nodarbības. Pirmais redzamais ieguvums ir tas, ka šie vecāki vairāk aizdomājas par savu veselību un iespējām to stiprināt. Šajā mikroprojektā sociālo un veselības pakalpojumu sniedzēju iesaistī̌sana grūtības nesagādāja. Organizējot apaḷā galda

Otrais cipars šai sadaḷā norāda partnera numerācijas secību projekta pieteikumā. Visi partneri mikroprojektus nav īstenojuši, tādēḷ skaiț̣i, kas norāda partnera numuru, neveido secīgu rindu (A. S.). 
diskusijas, notika veiksmīga domu apmaiņa, tika rasti interesanti risinājumi. Pagaidām lielākās grūtības ir bijušas, lai nodrošinātu pašu vecāku iesaistišanos mikroprojekta veidošanā, organizēšanā un turpināšanā.

Trešā mikroprojekta mērḳis ir nodrošināt bērnu pieskatî̌anas pakalpojumu tad, kad vecāks, kurš viens audzina bērnus, dodas uz konsultāciju pie ārsta. Šāds pakalpojums uzlabo veselības aprūpes pieejamību šiem vecākiem.

\subsection{Ziemeḷvācijas Evanggēliski luteriskā baznīca (Vācija)}

Šis projekta partneris ir izveidojis ilgstošo bezdarbnieku atbalsta grupu Wirkstatt (darbošanās vieta). Šì mikroprojekta galvenais uzdevums bija izveidot un iedzīvināt vietu, kur ilgtermiņa bezdarbnieki varētu tikties ar citiem cilvēkiem līdzīgā situācijā, komunicēt un sadarboties, kopīgi atpūsties bez papildu izmaksām, iesaistīties pieredzes apmaiņā. İstermiṇa ieguvums ir pašapziņas celšana, pārliecības par sevi nostiprināšana. Ilgtermiṇā tiks veidots kas līdzịgs politiskai pārstāvniecībai, mācību platforma un forums. Pagaidām šie mērḳi ir sasniegti dal̦ēji. Projekts ir labi zināms reg̣ionā. Tie dalībnieki, kuru situācija ir mainijusies uz labo pusi un kuriem atbalsta grupa vairs nav nepieciešama, no mikroprojekta izstājas. Interesi par iesaistišanos mikroprojektā ir izrādījuši vairāki jauni sociālo pakalpojumu sniedzēji. Kopumā darbs ir gana sarežg̀îts, jo atbalsta grupa ir trausla un heterogēna. Nav viegli saskaņot ilgstošu un l̦oti ilgstošu bezdarbnieku mērḳus, kas ievērojami atškiras. Wirkstatt dod iespēju darba devējiem satikt potenciālos darbiniekus.

\section{3. Šlēsvigas-Holšteinas Ekonomikas akadēmija (Vācija)}

Šis partneris mikroprojektu ir īstenojis, izveidojot mācību uzṇēmumu, kas bēgḷiem palīdz iesaistīties darba tirgū. Tajā tiek mācīta vācu valoda, tādējādi racionāli izmantojot gaidīšanas laiku, kamēr tiek veiktas dažādas ar bēgḷu statusa iegūšanu saistītas procedūras. Vajadzību apzināšanā tika noskaidrots, ka ir l̦oti daudz laika, kad bēgliem vienkārši jāgaida, kamēr notiek dažādas birokrātiskas procedūras - tiek apstiprināts bēg̣̣a statuss vai organizēta atgriešanās uz savu izcelsmes valsti. Mikroprojektā tiek piedāvāta iespēja uzsākt darba gaitas arī sievietēm. Lai arī izcelsmes valstīs bēgḷu sievietes lielākoties algotu darbu 
nestrādā, bet rūpējas par māju un bērniem, tomēr vajadzību apzināšanās sarunās sievietes izrādīja aktīvu interesi par iespējām iesaistīties darba tirgū un integrēties Vācijas sabiedrībā. Viṇas ir pamanījušas, ka Vācijā sievietes loma ir citādāka nekā vinu izcelsmes valstīs. Izglìtības līmenis bēglēm no Sirijas ir atškirīigs. Dažas bēgles ir studējušas, bet ir arī tādas, kas neprot lasìt un rakstīt. Projektā piedalās abu dzimumu bēgḷi. Viṇiem palīdz apgūt vācu valodu un tiek sniegts atbalsts darba meklēšanā. Sarežğìtākais šajā mikroprojektā ir starpkultūru komunikācija un saprašanās. Te jāmācās abām pusēm: gan iebraucējiem, gan vietējiem iedzīvotājiem - vāciešiem.

\subsection{Lietišķo zinātņu augstskola Novia (Somija)}

Šîs augstskolas mikroprojekta mērḳis ir apkopot vecāka gadagājuma cilvēkiem noderīgu informāciju no dažādiem avotiem, lai viṇi vienuviet varētu skatìt informāciju par interesantiem pasākumiem un noderīgām aktivitātēm. Tāds digitāls rīks varētu veicināt vecāka gadagājuma cilvēku līdzdalību pasākumos un mazināt vinu vientulību. Šim nolūkam ir radīts kalendārs internetā - vienkāršs digitāls instruments, ar kura palīdzību var vieglāk iegūt informāciju par notikumiem un iespējām reǵionā. Pakalpojumu sniedzēji šo digitālo instrumentu var izmantot pasākumu plānošanai. Tāpat tas var būt noderīgs dažādu jomu pārstāvju sadarbības veidošanai un plānošanai. Kalendārs sniedz kopskatu par regionā plānotajiem notikumiem un tādējādi palīdz ieraudzīt jomas un laika posmus, kuros aktivitāte ir zemāka un tāpēc ir iespējams vai nepieciešams iekḷaut papildinājumus. Šobrīd ir grūti novērtēt, cik veiksmīgs ir šis mikroprojekts, jo tikai pēc ilgāka laika varēs redzēt, vai kalendārs joprojām tiek izmantots, regulāri papildināts un tālāk attīstīts. Vecāka gadagājuma cilvēkiem, kuriem ir digitālā pratība, šis rīks palīdz uzzināt par pasākumu piedāvājumu un plānot savas aktivitātes. Vajadzība pēc prasmes darboties internetā arvien pieaug, un, iespējams, šis vienkāršais digitālais rīks var arī iedrošināt šos cilvēkus apgūt internetpratību.

\subsection{Jiveskiles-Kokolas Universitātes konsorcijs Chydenius (Somija)}

Šis projekta partneris mikroprojektu ir īstenojis divās daḷās. Sākumā ir uzņemta videofilma par migrantu prasmēm. Pēc tam ir 
nodibināta afgāṇu imigrantu NVO. Afgāṇu kopienai Kokolā nebija telpu, kur organizēt kopīgas tikšanās. Universitātes konsorcijs tās piedāvāja, kā arī uzklausīja vajadzības, palīdzēja veidot komunikāciju, plānot aktivitātes un dibināt NVO. Afgāņu kopienu iedrošināja tas, ka šajā projektā arī viṇi paši tiek sadzirdēti. Pēc pusgada kopīga darba un diskusijām tika nolemts dibināt NVO. Mikroprojektā afgāņu imigrantiem tika mācīts, kā noris demokrātisks lēmumu pieņemšanas process, kā pieteikties fondu projektiem, kā vadìt NVO. Tāpat tas veicināja līdzdalību dažādās aktivitātēs, kas tika rīkotas pilsētā. Jaundibinātā NVO sadarbojas ar pilsētas domi. Demokrātiska lēmumu pieņemšanas procesa apgūšana un funkcionējoša rīcībspēja Somijas kontekstā ir ārkārtīgi nozīmīga prasme, kas noteikti ir jāapgūst imigrantiem, kuri nokḷuvuši šajā valstī.

\subsection{Luterāņu diakonija (Lietuva)}

Lietuvas partneru veidotā mikroprojekta galvenais uzdevums ir identificēt viena vecāka gimenes un veidot to savstarpējas saiknes, organizēt pasākumus, kuros var apgūt organizatoriskas, vadības un uzṇēmējdarbības prasmes. Sākumā tika apzinātas vajadzības. Atklājās, ka nopietna šo cilvēku problēma ir bailes, pašapziņas un pašpārliecinātības trūkums, kā arī neziṇa, kur vērsties pēc palīdzības. Tādēl tika nolemts organizēt kopīgu pasākumu, lai cilvēki varētu satikties un izrunāties. Tas tika noorganizēts kopā ar dažādiem sociālo pakalpojumu sniedzējiem, papildus tika nodrošinātas dažādas atraktīvas aktivitātes - friziera pakalpojumi, spēles bērniem. Pasākums izdevās veiksmīgs, un šobrīd ir plāns piesaistīt valsts un privātus finansētājus, lai šādu pasākumu rỉkotu katru gadu.

Vēl šogad tiek plānota mācību programma, kurā zināšanu apguves priekšmeti būtu sociālais mārketings, mijiedarbība un komunikācija ar pakalpojumu lietotājiem, sevis prezentācijas prasmes un veiksmīgas konkurences nosacījumi darba tirgū. Lìdztekus ir izveidota laba sadarbība ar Lietuvas Nodarbinātības valsts aǵentūru, veicinot izpratni par individuālas pieejas nepieciešamību šai mērḳgrupai. Nākotnē tiek plānots izveidot klubu, kur viena vecāka gimenes varētu tikties, gūtu atbalstu, iedrošinājumu un zināšanas vadības un uzṇēmējdarbības jautājumos. 


\subsection{Igaunijas Evangêeeliski luteriskā baznīca (Igaunija)}

Te tiek īstenoti divi mikroprojekti. Viens mikroprojekts ir bērnudārza izveidošana, otrs ir atbalsta sniegšana no ieslodzijuma atbrīvotām personām.

Izpētot reg̣iona attīstības plānu un pašvaldībā pieejamos datus, tika secināts, ka Igaunijas ziemeḷaustrumu reǵionā ir nepieciešams bērnudārzs bērniem līdz trīs gadu vecumam. Lìdz šim regionā bija pieejami bērnudārzi tikai bērniem, kas jau sasnieguši trīs gadu vecumu. Bērnu vecāki mikroprojekta ideju atbalstīja. Kopīgi ar viniem tika rīkotas diskusijas, lai labāk izprastu vajadzības šì pakalpojuma kontekstā. Būtisks arguments par labu šim mikroprojektam ir tas, ka bērnudārza pakalpojuma nodrošināšana dod iespēju vecākiem strādāt algotu darbu.

Otrā mikroprojekta mērķis ir rekrutēt un izglìtot atbalsta personas tām personām, kas atbrīvotas no ieslodzījuma. Brīvprātīgiem tiek mācītas šim darbam nepieciešamās sociālā darba prasmes. Brīvprātīgo darbs tiek sākts, personai vēl esot brīvības atņemšanas iestādē. Brīvprātīgiem tiek mācīts, kā palīdzēt ieslodzìtajiem pašiem risināt savas problēmas un radušos sarežǵījumus. Pēc mācībām brīvprātīgie rỉko diskusiju ar ieslodzītajiem par viṇu vajadzībām. Šì mikroprojekta mērkisis ir veidot labāku izpratni par to, kā palīdzēt personām, kas notiesātas ar brīvības atņemšanu, saprast savas problēmas, to cēloṇus un kā pašām tās veiksmīgāk risināt. Pēc kopīgām diskusijām tiek veidoti individuāli plāni dzīvei pēc ieslodzījuma. Ar valsti ir noslēgts līgums par samaksu brīvprātīgajiem. Tie ir 7 eiro stundā. Brīvprātīgajiem tiek nodrošināta supervīzija. Kaut arī sākotnēji cietuma vadība un darbinieki izrādīja piesardzỉbu un nebija atvērti šim projektam, tomēr šobrīd visi ir atzinuši, ka brīvprātīgo regulārās tikšanās ar ieslodzītajiem ir nākušas par labu videi brīvības atņemšanas institūcijā.

\subsection{Sociālās rīcības fonds (Igaunija)}

Sociālās rīcības fonda veidotā mikroprojekta sākumā tika plānots Igaunijas ziemel̦austrumu un centrālā reǵionā organizēt nodarbību programmu skolēniem pēc mācību stundām skolā. Projekts paplašinājās, tajā iekḷaujot pasākumus pieaugušajiem. Mērḳis ir sekmēt reǵiona iedzīvotāju labklājību. Jaunākais papildinājums mikroprojektā ir bērnudārzs bērniem līdz trīs gadu vecumam. Mikroprojekta aktivitāšu rezultātā ir nostiprinājusies kopienas baznīcas ideja, kā arī 
izpratne par draudzīgas, savstarpēji izpalīdzīgas, dzīvi apliecinošas kopienas (conviviality) labvēlīgo ietekmi uz kopienas un indivīda dzīvi. Mikroprojekta rezultātā ir pieaugušas iespējas sniegt sociālos pakalpojumus regionā.

\subsection{Dienviddānijas Universitātes koledža (Dānija)}

Mikroprojekta "Kultūru šḳērsošana" (Crossing cultures) mērḳis ir darbs ar bēgliiem. Galvenā ideja ir spēcināt jaunos cilvēkus, kas Dānijā ieradušies kā bēgḷi, veidojot no viņu vides kodolu, kas palīdz iesaistīt citus bēglus un organizē viniiem spēcināšanas aktivitātes. Šiem cilvēkiem tiek palīdzēts, dodot iespēju palīdzēt citiem, būt tiem, kas spēcina citus. Bēg̣̣i, kas ieradušies Dānijā, tiek iedrošināti veltīt laiku citu cilvēku atbalstīšanai. Mikroprojektā iesaistītie dalībnieki paši meklē līdzekḷus un atbalstītājus ieplānotajiem projektiem. Ar padomiem viņiem palīdz projekta koordinators. Piemēram, šie jaunie cilvēki spēja piesaistīt līdzekḷus un noorganizēja lieliskas brīvdienas viena vecāka ǵimenēm. Mikroprojektā iesaistīto un iesaistijušos grupa nu jau attīstās patstāvīgi un palīdz attīstìties citiem. Viņiem ir dažādi resursi, un viņi var palīdzēt un palīdz tiem, kam resursu trūkst. Šo bēg̣̦u darba rezultātā gan vini, gan citi cilvēki piederību kopienai izjūt arvien stiprāk.

Mikroprojektu apskats rāda, cik tie ir dažādi, jo dažādas ir sociālo pakalpojumu lietotāju kategorijas. Kopīgais secinājums par mikroprojektiem ir tāds, ka tie visi ir uzlabojuši dzīves kvalitāti tiem, kas iesaistijās mikroprojektu īstenošanā.

\section{Trūcīgo un maznodrošināto daudzbērnu gimeñu iesaistīšana savas labklājības veidošanas darbā Latvijā}

Noslēgumā ilustrācijai konkrēts piemērs par sociālo pakalpojumu galalietotāju iesaistī̌sanu savas labklājības veidošanā Latvijā.

Latvijas pilsoniskās sabiedrības pārstāvji (NVO), pašvaldības un privāts fonds ir devuši iespēju trūcīgām un maznodrošinātām gímenēm izaudzēt sev pārtikai dārzeņus, ogas un aug̣̦us. Tā ir iesaistî̌anas iniciatīva sava dārza iekopšanā, lai ar sava darba ieguldījumu 
pašvaldību pieškiirtos zemes gabalos un ar citu cilvēku sagādāto sēklu materiālu un nepieciešamāko inventāru lielā mērā nodrošinātu sevi un savu gimeni ar pārtiku.

\section{Latvijas trūcīgo un maznodrošināto daudzbērnu giimeņu iesaistīšana rīcībā, lai spēcinātu savu labklājību}

Šis ir piemērs par Latvijas lokālās spēcināšanas tīklu sarūpēto un piedāvāto iespēju sociālo pakalpojumu galalietotājiem iesaistīties pārtikas sagādē savai ǵimenei. Šo iespēju nodrošina nevalstiskās organizācijas, lauku apdzīvoto vietu pašvaldības un Borisa un Ināras Teterovu fonds kā izdevumu finansētājs. Projekta mērḳgrupa ir trūcīgās un maznodrošinātās daudzbērnu gimenes, kas dzīvo laukos un lieto sociālos pakalpojumus. Borisa un Ināras Teterovu fonds sociālo pakalpojumu lietotāju iesaistišanu un spēcināšanu finansē, izveidojot šim nolūkam finansējuma programmu "Pats savam saimes galdam". Programma visā Latvijas lauku teritorijā darbojas kopš 2017. gada, un tiek plānots to îstenot trīs gadus. 2018. gadā lokālās spēcināšanas organizācijas tika aicinātas līdz 31. janvārim pieteikties finansējuma saņemšanai no fonda un vienlaicīgi ar pieteikumu iesniegt izdevumu tāmi par to, ko nepieciešams iegādāties, lai nodrošinātu darbošanos tām ğimenēm un atsevišḳiem indivīdiem, kas pauduši gribu iesaistīties.

Atbalsta sniegšanā trūcīgām un maznodrošinātām daudzbērnu ǵimenēm laukos ir iesaistîti un ieinteresēti vietējo pašvaldību sociālie dienesti, lokālās sabiedriskās organizācijas, kopienu fondi, religískās organizācijas un Borisa un Ināras Teterovu fonds, kas piekritis šo iniciatīvu un projektu finansēt. Šĩ pasākuma norisi organizē lokālā sociālās spēcināšanas tīkla organizācija, kas ir atbildīga par programmas "Pats savam saimes galdam" īstenošanu. Tā informē un uzaicina iesaistīties tos vietējos iedzīvotājus, kam pašu darbs un piedalīšanās šādā programmā sniegtu jūtamu atbalstu pārtikas nodrošināšanā. Programma "Pats savam saimes galdam" par brīvu piedāvā dārzeņu un kartupeḷu sēklas, augģ kocinus un ogu krūmus, dažos gadījumos arī minerālmēslojumu un kaut ko no lauksaimniecības inventāra, lai trūcīgās daudzbērnu ǵimenes un atsevišķi iedzīvotāji varētu izaudzēt 
sev pārtiku. Tā tiktu sagādāta nozīmīga pārtikas dala. Sadarbības tīkla organizācijas apzina un uzaicina iesaistīties sociālo pakalpojumu galalietotājus, pašvaldības piešķir lietošanā zemi, kur ierīkot dārzu. Tā, izmantojot piedāvāto iespēju par brīvu saņemt visu nepieciešamo darbam, pieņemot šo piedāvājumu, sociālo pakalpojumu galalietotāji reǵionos ar savu darbu var kḷut labāk nodrošināti, materiāli un psiholoǵiski labklājīgāki un pašapziñā spēcīgāki.

Statistiskie dati rāda, ka 2017. gadā šajā programmā iesaistījās 436 trūcīgās un maznodrošinātās daudzbērnu ǵimenes, aptverot 1581 cilvēku, to skaitā 778 bērnus, 21 Latvijas novadā. Šìs ǵimenes saimniekoja uz $400 \mathrm{~m}^{2}$ zemes un izaudzēja 86000 kg dārzeņu. Visbiežāk audzēja kartupel̦us, sīpolus, burkānus, tomātus, bietes un gurksus.

2018. gadā šĩ programma netika īstenota, bet tā atsāks darbu 2019. gadā.

Avots: Borisa un Ināras Teterovu fonds aicina klūt par saimniekiem savam saimes galdam. Pieejams: www.teterovufonds.lv [28.01.2018., 02.01.2019.].

\section{Secinājumi}

Iesaistī̌sana un iesaistǐšanās ir sabiedrības demokrātiskas pārvaldības un varas sadalīšanas un pārdalīšanas instruments.

Iesaistī̌̌ana un iesaistīšanās sociālās labklājības sfērā ir pieeja, kas ir aktualizēta kā inovatīvs instruments, jo sociālo pakalpojumu jomā kādu laiku tas nav ticis izmantots kā pārmainu instruments un dzīves kvalitāti uzlabojoša sociālā tehnolog̣ija.

Apzinoties nepieciešamību aktivizēt sociālo pakalpojumu galalietotāju domāšanu un rīcību, lai viņi aktīvi veiktu pārmaiņas savā dzīves situācijā, viṇi sākumā kopā ar nozares profesionāliem ir iesaistāmi savu vajadzību apzināšanas procesā.

Praksē ir pierādīts, ka vienkāršas un efektīvas iesaistīšanas metodes savu vajadzību apzināšanā ir, pirmkārt, àtrais līdzdalīgais novērtējums, otrkārt, tā dēvētā mugursomas metode, treškārt, nākotnes darbnīca un, ceturtkārt, log̣iskās strukturēšanas pieeja. 
Vajadzību apzināšanai seko praktiska rīcība, lai apmierinātu patiesi nepieciešamās vajadzības.

Kā iespējamais iedvesmas avots pārdomām par rīcību, rīcības plānošanai un pašai praktiskai rīcībai rakstā ir sniegta virkne labas prakses piemēru no SEMPRE projekta partnerības valstu pieredzes un SEMPRE projekta partneru īstenoto mikroprojektu prakses, kā pašu spēkiem uzlabot dzīves un vides kvalitāti.

Kopumā cilvēku iesaistǐšana un iesaistǐšanās aktīvā rīcībā var zināmā mērā mainīt un uzlabot sociālo pakalpojumu galalietotāju dzīves apstākḷus gan lauku, gan pilsētas vidē.

\section{Atsauces}

Borisa un Ināras Teterovu fonds aicina kḷūt par saimniekiem savam saimes galdam. Pieejams: www.teterovufonds.lv [skatits: 28.01.2018., 02.01.2019.].

Elisheva, S. Empowerment and Community Planning. Part 1. Developing a Theory of Empowerment. Available: www.mpow.org/elisheva_sadan_empowerment_ part1_intro.pdf [accessed: April 8, 2018.].

Elisheva, S. Empowerment and Community Planning. [b.g.] 350 p. Available: http:// www.mpow.org/elisheva_sadan_empowerment.pdf [accessed: May 4, 2018.].

Schrötter Johannsen, G. (2018) Empowerment. The Power to Name - the Power to Act. Handouts in Workshop in Esbjerg on February 26, 2018.

\section{leteicamā literatūra un avoti papildu informācijai par iesaistî̌sanu un iesaistišanos ${ }^{3}$}

\section{Grāmatas, rokasgrāmatas, brošūras}

Aldridge, J. (2015) Participatory Research: Working with Vulnerable Groups in Research and Practice. Policy Press.

Barnes, M., Cotterell, P. (2012) Critical Perspectives on User Involvement. The Policy Press.

Beresford, P. (2012) Social Care, Service Users and User Involvement (Research Highlights in Social Work Series). Jessica Kingsley Pub.

Literatūras un avotu sarakstu par iesaistǐšanu/iesaistǐ̌anos veidojušas Evija Zača, Laura Jaunromāne un Anna Stepčenko. Sarakstu sakārtojusi atbilstoši bibliogrāfijas normām Lìva Upena (A. S.). 
Branfield, F., Beresford, P. with contributions from Andrews, E. J., Chambers, P., Staddon, P., Wise, G., Williams-Findlay, B. (2006) Making User Involvement Work: Supporting Service User Networking and Knowledge. Joseph Rowntree Foundation. Available: https://www.jrf.org.uk/sites/default/files/jrf/migrated/ files/1410-user-networking-knowledge.pdf.

Community-Based Participatory Research: A Guide to Ethical Principles and Practice (2012) Centre for Social Justice and Community Action, Durham University; National Co-ordinating Centre for Public Engagement (United Kingdom).

Croft, S., Beresford, P. (1993) Citizen Involvement: A Practical Guide for Change (Practical Social Work Series). Palgrave Macmillan.

Greenhalgh, T., Humphrey, C., Woodard, F. (2011) User Involvement in Health Care. Blackwell Publishing Ltd.

Kaasinen, E., Ainasoja, M., Vulli, E., Paavola, H., Hautala, R., Lehtonen, P., Reunanen, E. (2010) User Involvement in Service Innovations. VTT. Available: http://www.vtt.fi/inf/pdf/tiedotteet/2010/T2552.pdf.

Lowes, L., Hulatt, I. (2005) Involving Service Users in Health and Social Care Research. Routledge.

Participation Toolkit (2013) Available: http://www.feantsa.org/spip.php?article 122\&lang=en; available in following languages: English, Catalan, French, German, Polish, Spanish.

Payne, M. (2014) Modern Social Work Theory (4th ed.). Basingstoke: Palgrave Macmillan.

Roy, H. (2015) User Participation and Empowerment Toolkit. Eurodiaconia.

Social Innovation: The Role of Social Service Providers (2012) Social Services Europe.

Tyler, T. R. (2011) Why People Cooperate: The Role of Social Motivations. Princeton University Press.

Trotter, C. (1999) Working with Involuntary Clients: A Guide to Practice. Sage Publications.

Warren, J. (2007) Service User and Carer Participation in Social Work. SAGE.

\section{Raksti}

Beresford, P., Croft, S. Service Users' Knowledge and the Social Construction of Social Work. Journal of Social Work. Vol. 1, No. 3, December 2001, pp. 295-316. Doi: 10.1177/146801730100100304.

Cossar, J., Neil, E. Service User Involvement in Social Work Research: Learning from an Adoption Research Project. British Journal of Social Work. Vol. 45, No.1, 2015, pp. 225-240. Doi: 10.1093/bjsw/bct108.

Cowden, S., Singh, G. The 'User': Friend, Foe or Fetish?: A Critical Exploration of User Involvement in Health and Social Care. Critical Social Policy. Vol. 27, No. 1, February 2007, pp. 5-23. Doi: 10.1177/ 0261018307072205. 
D'Cruz, H., Gillingham, P. Participatory Research Ideals and Practice Experience: Reflections and Analysis. Journal of Social Work. April 22, 2016. Doi: $10.1177 / 1468017316644704$.

Fleming, J., Beresford, P., Bewley, C., Croft, S., Branfield, F., Postle, K., Turner, M. Working Together - Innovative Collaboration in Social Care Research. Qualitative Social Work. Vol. 13, No. 5, September 2014, pp. 706-722. Doi: $10.1177 / 1473325013506929$.

Kujala, S. User Involvement: A Review of the Benefits and Challenges. Behaviour \& Information Technology. 2003, pp. 1362-3001. Doi: 10.1080/ 0144929021000055530.

Kvarnström, S., Hedberg, B., Cedersund, E. The Dual Faces of Service User Participation: Implications for Empowerment Processes in Interprofessional Practice. Journal of Social Work. Vol. 13, No. 3, May 2013, pp. 287-307. Doi: $10.1177 / 1468017311433234$.

Littlechild, R., Tanner, D., Hall, K. Co-research with Older People: Perspectives on Impact. Qualitative Social Work. Vol. 14, January 1, 2015, pp. 18-35. Doi: $10.1177 / 1473325014556791$.

Loughran, H., McCann, M. E. Employing Community Participative Research Methods to Advance Service User Collaboration in Social Work Research. British Journal of Social Work. Vol. 45, No. 2, 2015, pp. 705-723. Doi: 10.1093/ bjsw/bct133.

Mclaughlin, H., Brown, D., Alys, M. Young Consultation, Community and Empowerment: Lessons from the Deaf Community. Journal of Social Work. August 2004. Doi: 10.1177/1468017304044859.

Smith, M., Gallagher, M., Wosu, H., Stewart, J., Cree, V. E., Hunter, S., Evans, S., Montgomery, C., Holiday, S., Wilkinson, H. Engaging with Involuntary Service Users in Social Work: Findings from a Knowledge Exchange Project. British Journal of Social Work. Vol. 42, No. 8, 2012, pp. 1460-1477.

Storm, M., Hausken, K., Knudsen, K. Inpatient Service Providers' Perspectives on Service User Involvement in Norwegian Community Mental Health Centres. International Journal of Social Psychiatry. Vol. 57, No. 6, November 2011, pp. 551-563. Doi: 10.1177/0020764010371270.

West, S. A., Griffin A. S., Gardner, A. Social Semantics: Altruism, Cooperation, Mutualism, Strong Reciprocity and Group Selection. Journal of Evolutionary Biology. Vol. 20, No. 2, March, 2007, pp. 415-432. Doi: 10.3410/ f.1071807.524727.

\section{Interneta resursi}

Homepage of European Social Network. $\rightarrow$ Page: Empowering people with disabilities through service-user participation. Available: http://www.essc-eu. org/essc-workshops/empowering-people-with-disabilities-through-serviceuser-participation/.

Homepage of Social Services Europe. $\rightarrow$ Page: PESSIS - Promoting employers' social services in social dialogue. Available: http://www.socialserviceseurope. $\mathrm{eu} / \#$ !pessis-/c7pr. 


\section{Raksti internetā}

Active Inclusion of People with Disabilities: the Role of Public Social Services. Available: http://www.esn-eu.org/news/729/index.html.

'Complaints, Legal Assistance and Rights Information Tool for You'. Available: http://www.socialplatform.org/news/complaints-legal-assistance-and-rights-information-tool-for-you/.

Decentralisation at the Crossroads. Available: http://www.esn-eu.org/news/802/ index.html.

Empowering Communities for Better Outcomes. Available: http://www.esn-eu. org/news/804/index.html.

Fundamental Rights Based Governance. Available: http://www.socialplatform. org/blog/fundamental-rights-based-governance/.

How can Social Care Providers Involve Service Users? Available: https://www. theguardian.com/social-care-network/2014/may/22/social-care-providers-involve-service-users.

Integrated Services for People with Disabilities. Available: http://www.esn-eu. org/news/600/index.html.

Integrated Social Services in Europe. Available: http://www.esn-eu.org/ news/746/index.html

Involvement of People with Disabilities: the Key to Adequate, Person-Centred Services? Available: http://www.esn-eu.org/news/769/index.html.

Local Partnerships for Social Inclusion. Available: http://www.esn-eu.org/news/ 801/index.html.

Local Strategies for Social Cohesion. Available: http://www.esn-eu.org/news/ 800/index.html.

Partnership between the Public Sector and Civil Society: Win-Win for Social Services. Available: http://www.socialplatform.org/blog/partnership-betweenthe-public-sector-and-civil-society-win-win-for-social-services-1/.

Quality, Person-Centred Services for People with Disabilities. Available: http:// www.esn-eu.org/news/561/index.html.

Social Work Education Leads the Way on Involving Service Users. Available: https://www.theguardian.com/social-care-network/2014/jun/03/social-workeducation-leads-way-involving-service-users.

Stakeholder Involvement can Improve Poverty and Social Exclusion Policies. Available: http://www.socialplatform.org/news/more-ambitious-stakeholderinvolvement-for-better-policies/

Working Strategically with Service Users. Available: http://www.esn-eu.org/ news/491/index.html.

\section{Videomateriāli}

$23^{\text {rd }}$ European Social Services Conference Video. Available: https://vimeo. com/148864200. 
Closing Panel Discussion: What are the Outcomes of Integrated Services for Organisations and Service Users? Available: https://vimeo.com/147008631. CRCC Health and Wellbeing - Service User Involvement. Available: https:// www.youtube.com/watch?v=AkzPc9wHWdc.

European Social Rights Pillar: Developing Inclusive Labour Markets. Available: https://vimeo.com/177216024.

Listening to Users and Carers. Available: https://vimeo.com/10523104.

Service User Involvement: Unique and Essential. Available: https://www.youtube.com/watch?v=Ixeclxg3cAY.

The Benefits of Service User Involvement. Available: https://www.youtube. $\mathrm{com} /$ watch?v=iVAwbgTdT6A.

The MHRN and Service User Involvement. Available: https://www.youtube. $\mathrm{com} /$ watch? $\mathrm{v}=\mathrm{V} 8 \mathrm{C} 8 \mathrm{w} Y \mathrm{lPuuk}$.

The NHS: User Involvement and You. Available: https://www.youtube.com/ watch?v=5xhs0I_DInw. 